\title{
PENGGUNAAN MODUL BERORIENTASI MODEL PEMBELAJARAN INKUIRI TERBIMBING PADA MATERI MOMENTUM DAN GERAK HARMONIK UNTUK PENINGKATAN KOMPETENSI FISIKA PESERTA DIDIK
}

\author{
Nita Adzaniah Akbar ${ }^{1)}$ Hidayati $^{2)}$ Masril $^{2)}$ \\ ${ }^{1)}$ Mahasiswa Pendidikan Fisika, FMIPA Universitas Negeri Padang \\ ${ }^{2)}$ Staf Pengajar Jurusan Fisika, FMIPA Universitas Negeri Padang \\ nitaadzaniahakbar119@gmail.com \\ hidayati@fmipa.unp.ac.id \\ masril_qch@yahoo.com
}

\begin{abstract}
Increasing the achievement of physics competence of learners can be done one of them with the use of varied teaching materials, as well as the use of learning models that can improve learning activities of learners. This study aims to determine the effect of the use of oriented modules of guided inquiry learning model toward the achievement of physics competence of students of class X SMAN 2 Padang Panjang. This research is classified as Pre-Experimental Design with One Shot Case Syudy design. The population used is all students of class X academic year 2016/2017. The sample is determined using purposive sampling technique. The data of this research include attainment of attitudinal competence data, knowledge and skill. The attainment of attitudinal competence data was obtained through the observation appraisal sheets, then described and analyzed in graphical form. Data on the achievement of knowledge competence is obtained through posttest. Data on the achievement of skills competence is obtained through performance assessment sheet. Data on the achievement of knowledge and skills competencies are then linked to the value of learning using guided inquiry-oriented model modules. The result of attitude attitude data analysis which is depicted through the graph shows result which tend to change every meeting. Data on the achievement of knowledge and skills competencies were analyzed using simple linear regression test and test of two variable relationship. The result of analysis shows that there is an influence between the use of guided inquiry model oriented module with the achievement of knowledge and skill competence of $21.26 \%$ and $20.27 \%$.
\end{abstract}

Keywords : Module, Giuded Inquiry Learning, Students Physics Competence

\section{PENDAHULUAN}

Pendidikan merupakan salah satu pilar utama dalam mengantisipasi masa depan dan pendidikan merupakan instrumen penting bagi setiap bangsa dalam meningkatkan daya saing dalam kehidupan masyarakat global. Banyak negara maju terus membangun sektor pendidikannya dengan tujuan meningkatkan investasi dalam bidang pendidikan.

Indonesia sebagai salah satu negara berkembang tidak boleh tertinggal dalam membangun dunia pendidikannya. Memiliki wilayah yang luas dan jumlah penduduk yang banyak, pendidikan di Indonesia sering dihadapkan dengan masalah kualitas dan pemerataan. Pendidikan yang tidak merata akan menghasilkan kualitas yang rendah, karena di daerah yang pendidikannya selalu mendapat perhatian dari pemerintah akan terus maju sedangkan yang tidak akan tetap tertinggal. Upaya yang terus dilakukan pemerintah diantaranya melakukan kegiatan seperti mengadakan pendidikan dan latihan profesi guru, penataran dan sertifikasi demi pengkatan kualitas dan kompetensi guru dalam bidangnya. Pemerintah juga melakukan kegiatan SM3T sebagai langkah pemerataan pendidikan diseluruh tanah Indonesia. Selain itu pemerintah juga telah melakukan penyempurnaan kurikulum dan pembenahan sarana dan prasarana pendidikan.

Upaya yang telah dilakukan pemerintah harusnya juga didukung oleh pelaksana pendidikan seperti guru dalam kegiatan pembelajaran. Namun kenyataannya, masih banyak guru yang belum menggunakan bahan ajar yang memfasilitasi peserta didik dalam pembelajaran. Padahal, seyogyanya salah satu tugas guru adalah menyediakan bahan ajar. Selain itu, pelaksanaan kegiatan praktikum juga masih jarang dilakukan meskipun sekolah sudah memiliki peralatan yang cukup lengkap. Banyak alasan yang menyebabkan pelaksanaan kegaiatan praktikum masih jarang dilakukan, diantaranya ketersediaan lembar kerja peserta didik masih sangat kurang. Pada umumnya di sekolah hanya tersedia lembar kerja yang dibuat oleh tim MGMP dan hanya berisikan lembaran-lembaran soal. Ketersediaan waktu juga sering menjadi alasan. Kejar materi untuk pelaksanaan ujian akhir membuat pelaksanaan praktikum menjadi dikesampingkan. Padahal melalui kegiatan praktikum peserta didik dapat membandingan dan menemukan kecocokan antara teori yang ia pelajari dengan hasil yang diperoleh dalam kegiatan praktikum. 
Penggunaan bahan ajar dalam pembelajaran memiliki peran penting, baik bagi guru maupun bagi peserta didik. Bagi guru, dengan adanya bahan ajar maka guru memiliki pedoman mengenai kompetensi yang harus disampaikan dalam kegiatan pembelajaran dan bagi peserta didik dapat dijadikan pedoman mengenai kompetensi yang harus dikuasai dalam kegiatan pembelajaran ${ }^{[1]}$. Bahan ajar dapat berupa bahan ajar cetak maupun non cetak. Salah satu contoh bahan ajar cetak adalah modul.

Penggunaan modul dalam pembelajaran dapat menjadikan pembelajaran lebih efektif dan efisien. Sebuah modul setidaknya berisikan petunjuk belajar (petunjuk untuk guru dan peserta didik), kompetensi yang akan dicapai, content atau materi, informasi pendukung, latihan, evaluasi serta balikan terhadap hasil evaluasi ${ }^{[2]}$.

Penggunaan modul dapat dijadikan sebagai salah satu cara untuk meminimalisir kebiasaan peserta didik untuk selalu mengulur-ulur waktu dalam pembelajaran, misalnya alasan sering meminta waktu untuk mencatat materi yang dijelaskan oleh guru. Hal ini menyebabkan waktu banyak terbuang. Jika pembelajaran dilengkapi dengan modul, maka materi yang dijelaskan oleh guru tersedia di dalam modul dan menjadikan waktu pembelajaran lebih efisien dan tujuan pembelajaran dapat tercapai.

Dalam sebuah modul dapat dimuat lembar kerja yang dapat digunakan peserta didik dalam kegiatan praktikum. Pelaksanaan kegiatan praktikum dapat memberikan kesempatan kepada peserta didik dalam membangun dan memperoleh pengetahuannya sendiri, karena pada hakikatnya pengetahuan yang diperoleh peserta didik berdasarkan pada pengalamannya sendiri akan bertahan lebih lama dibandingkan jika ia hanya menerima dan mendengar dari orang lain ${ }^{[3]}$.

Modul juga dapat divariasikan dengan memuat langkah model pembelajaran di dalamnya. Model pembelajaran yang dipilih juga harus sesuai dengan karakteristik peserta didik dan dapat melatih peserta didik belajar aktif dalam membangun pengetahuannya. Peserta didik harus dijadikan sebagai subjek pembelajaran bukan lagi sebagai objek, sebagaimana pembelajaran dalam kurikulum 2013. Salah satu model pembelajaran yang dapat diintegrasikan di dalam modul adalah model pembelajaran inkuiri.

Pembelajaran dengan model inkuiri akan membantu peserta didik mengenali fenomena yang terjadi. Hal ini dikarenakan dalam pembelajaran berbasis inkuiri bersifat real life artinya permasalahan di dalam inkuiri merupakan masalah yang diambil dari kehidupan nyata sehingga diyakini mampu membekali peserta didik dengan pengetahuan, keterampilan, dan sikap yang dibutuhkan dalam kehidupan keseharian ${ }^{[4]}$.

Penerapan model inkuiri dapat digunakan sebagai salah satu alternatif dalam upaya peningkatan kompetensi peserta didik. Hal ini diketahui setelah dilakukan penelitian bahwa penerapan model inkuiri dalam pembelajaran memberikan pengaruh yang signifikan terhadap kompetensi fisika peserta didik pada aspek pengetahuan kelas X SMAN 13 Padang ${ }^{[10]}$. Sejalan dengan itu penelitian lain yang juga menerapkan model pembelajaran inkuiri di dalamnya juga memberikan pengaruh terhadap kompetensi peserta didik. Hal ini terlihat dari peningkatan hasil belajar sebelum dan sesudah diberikan perlakuan yakni sebesar $15 \%$ pada aspek pengetahuan, serta pada aspek keterampilan terjadi peningkatan $13 \%^{[10]}$.

Pembelajaran berbasis inkuiri merupakan pembelajaran dengan penyelidikan dan peserta didik melibatkan seluruh kemampuannya secara maksimal untuk mencari dan menyelidiki secara sistematis, kritis dan logis sehingga mereka dapat merumuskan sendiri penemuannya dengan rasa percaya diri ${ }^{[5]}$. Karena peserta didik dapat dikatakan masih terbilang awal belajar dengan metode penyelidikan, maka dalam pelaksanaannya peserta didik masih memerlukan bimbingan dan arahan dari guru. Untuk itu model pembelajaran yang digunakan dalam penelitian ini adalah model pembelajaran inkuiri terbimbing.

Pembelajaran dengan inkuiri terbimbing dimulai dengan kegiatan orientasi, merumuskan masalah, mengajukan hipotesis, mengumpulkan data, menguji hipotesis, hingga merumuskan kesimpulan. Dalam pembelajaran berbasis model inkuiri terbimbing, peran guru sangat dibutuhkan yakni dalam mengemukakan bermacam pertanyaan yang mampu meningkatkan rasa ingin tahu peserta didik. Guru tidak langsung memberikan jawaban yang benar, melainkan guru memberikan peserta didik kesempatan untuk mengemukakan pendapatnya. Dari berbagai pendapat yang dikemukakan guru harus bisa menggiring pemikiran peserta didik menuju suatu jawaban dan kesimpulan yang benar ${ }^{[8]}$.

Selain itu, pembelajaran menggunakan model inkuri terbimbing dapat dijadikan sebagai sarana pemenuhan rasa ingin tahu peserta didik, karena melalui demonstrasi yang diberikan oleh guru akan menimbulkan pertanyaan dalam diri peserta didik, dari pertanyaan tersebut timbul keinginan untuk mendapatkan suatu jawaban. Guru dapat memberikan kata kunci untuk memberikan kemungkinan jawaban yang benar sehingga peserta didik berani untuk merumuskan sebuah hipotesis, hingga diperoleh suatu jawaban yang benar melalui serangkaian kegiatan yang sistematis.

Penggunaan model pembelajaran inkuiri terbimbing ini sangat membantu dalam melatih peserta didik untuk belajar mandiri dalam mengkonstruksi pengetahuannya. Oleh karena itu penggunaan modul berorientasi model pembelajaran inkuiri terbimbing ini diharapkan akan memberikan pengaruh dan dapat meningkatkan kompetensi 
peserta didik, baik kompetensi sikap, pengetahuan dan keterampilan.

\section{METODE PENELITIAN}

Penelitian ini tergolong ke dalam PreExperimental Designs. Dalam penelitian ini masih terdapat variabel luar yang ikut berpengaruh terhadap terbentuknya variabel terikat ${ }^{[6]}$. Hasil penelitian yang yang merupakan variabel terikat, nantinya tidak hanya dipengaruhi oleh treatment (variabel bebas) yang peneliti terapkan, karena masih ada variabel kontrol yang tidak dapat dikendalikan oleh peneliti.

Penelitian ini menggunakan rancangan One Shot Case Study, yaitu dengan menggunakan satu kelas sampel untuk melihat pengaruh dari perlakukan atau treatment yang diberikan yaitu penggunaan modul berorientasi model pembelajaran inkuiri terbimbing.

Populasi dalam penelitian ini adalah seluruh peserta didik kelas X SMAN 2 Padang Panjang yang terdaftar pada semester genap Tahun Ajaran 2016/2017. Pengambilan sampel dilakukan dengan teknik purposive sampling. Berdasarkan tujuan penelitian yang telah diungkapkan, peneliti memilih kelas dengan nilai kedua terendah dari semua kelas $\mathrm{X}$ MIPA yaitu kelas X MIPA1.

Penelitian ini memiliki dua variabel yaitu variabel terikat dan bebas. Variabel bebas dalam penelitian ini yaitu penggunaan modul berorientasi model pembelajaran inkuiri terbimbing. Sedangkan variabel terikat adalah pencapaian kompetensi fisika peserta didik kelas X SMAN 2 Padang Panjang.

Data yang digunakan dalam penelitian ini adalah data yang peneliti kumpulkan langsung selama kegiatan penelitian. Data tersebut meliputi data pencapaian kompetensi sikap, pengetahuan dan keterampilan. Data pencapaian kompetensi sikap dikumpulkan melalui penilaian lembar observasi sikap selama proses pembelajaran. Data pencapaian kompetensi pengetahuan dikumpulkan melalui tes akhir berupa posttest dan nilai proses pembelajaran pada setiap langkah model pembelajaran inkuiri terbimbing yang terdapat di dalam modul. Sedangkan data pencapaian kompetensi keterampilan diperoleh melalui penilaian unjuk kerja melalui rubrik penskoran selama kegiatan praktikum.

Penelitian ini dilakukan dengan tiga tahapan, yaitu tahap persiapan, pelaksanaan dan penyelesaian. Pada tahap persiapan, peneliti harus mempersiapkan segala sesuatu yang dibutuhkan dalam kegiatan penelitian, seperti menentukan tempat dan jadwal penelitian, mengajukan surat izin penelitian, mempersiapkan RPP dan modul penelitian, instrumen penelitian, menentukan populasi dan sampel. Pada tahap pelaksanaan kegiatan yang dilakukan adalah melaksanakan pembelajaran di kelas sampel dengan menggunakan modul berorientasi model pembelajaran inkuiri terbimbing. Pada tahap penyelesaian dilakukan dengan memberikan posttest pada kelas sampel guna melihat pengaruh dari treatment yang diberikan.

Penilaian kompetensi sikap dilakukan melalui lembar penilaian observasi selama pembelajaran berlangsung. Penilaian kompetensi pengetahuan dilakukan dalam bentuk ujian tertulis yaitu posttest di akhir penelitian dan penilaian proses pembelajaran pada setiap langkah dalam model pembelajaran inkuiri terbimbing. Penilaian kompetensi keterampilan dilakukan selama kegiatan percobaan melalui rubrik penskoran yang sesuai.

Instrumen penilaian kompetensi sikap dalam penelitian ini adalah lembar observasi yang formatnya sesuai dengan Permendikbud Nomor 104 tahun 2014 dan aspek sikap yang dinilai dibatasi pada sikap jujur, rasa ingin tahu, kerja sama dan percaya diri.

Instrumen penilaian kompetensi pengetahuan dalam penelitian ini adalah lembar soal pilihan ganda dengan lima pilihan jawaban. Soal tersebut harus dianalisis atau diuji terlebih dahulu tingkat validitas, reliabilitas, tingkat kesukaran dan daya bedanya agar menjadi suatu alat ukur yang baik. Dalam penelitian ini validitas yang akan diuji adalah validitas content. Content dari sebuah instrumen dikatakan valid jika isi di dalam instrumen tersebut sudah representatif secara keseluruhan materi yang harus diujikan ${ }^{[7]}$. Instrumen dikatakan reliabel jika instrumen konsisten terhadap hasil pengukurannya ${ }^{[7]}$. Tingkat kesukaran merupakan angka yang menunjukkan sukar atau mudahnya sebuah soal. Suatu instrumen memiliki daya beda yang baik apabila dapat membedakan antara peserta didik yang pandai dengan yang kurang pandai $^{[6]}$. Selain itu, instrumen yang digunakan dalam penilaian kompetensi pengetahuan adalah rubrik penskoran penilaian proses pembelajaran menggunakan modul berorientasi model pembelajaran inkuiri terbimbing yang dilakukan selama kegiatan pembelajaran. Langkah di dalam model pembelajaran inkuiri terbimbing ini meliputi: orientasi, merumuskan masalah, megajukan hipotesis, mengumpulkan data, menguji hipotesis, dan merumuskan kesimpulan.

Instrumen penilaian kompetensi keterampilan yang digunakan adalah rubrik penskoran penilaian unjuk kerja selama pelaksanaan kegiatan praktikum.

Data kompetensi sikap yang dikumpulkan dengan teknik observasi akan diperoleh dalam bentuk skor, kemudian skor dikonversi menjadi nilai dalam rentang 0-100. Nilai yang diperoleh kemudian diplot ke dalam grafik dan dideskripsikan untuk melihat pencapaian kompetensi sikap peserta didik setiap pertemuannya.

Data pada kompetensi pengetahuan dianalisis menggunakan uji regresi linier sederhana dan uji hubungan dua variabel. Uji regresi linier sederhana didasarkan pada hubungan fungsional satu variabel independen dengan satu variabel dependen. Secara 
umum persamaan regresi linier sederhana dapat dituliskan sebagai barikut:

$$
\hat{Y}=a+b X \text {. }
$$

Dimana $Y$ adalah subyek dalam variabel dependen (terikat), a merupakan harga $\mathrm{Y}$ ketika harga $\mathrm{X}=0$ (konstan), b merupakan angka arah atau koefisien regresi, $\mathrm{X}$ merupakan subyek pada variabel independen (bebas). Dalam penelitian ini variabel $\mathrm{X}$ adalah penggunaan modul berorientasi model pembelajaran inkuiri terbimbing dan $\hat{Y}$ adalah pencapaian kompetensi fisika peserta didik.

Untuk mengetahui adanya hubungan antara variabel independen dengan variabel dependen, dilakukan uji hubungan antara 2 variabel. Uji hubungan 2 variabel dengan $\mathrm{H}_{0}$ adalah tidak adanya hubungan antara variabel $\mathrm{X}$ dan $\mathrm{Y}$ dan $\mathrm{H}_{\mathrm{i}}$ adalah ada hubungan antara variabel $\mathrm{X}$ dan $\mathrm{Y}$, dilakukan perhitungan koefisien $\mathrm{r}$ menggunakan rumus sebagai berikut:

$$
r_{x y}=\frac{n \sum x_{i} y_{i}-\left(\sum x_{i}\right)\left(\sum y_{i}\right)}{\sqrt{n \sum x_{i}^{2}-\left(\sum x_{i}\right)^{2}\left(n \sum y_{i}^{2}-\left(\sum y_{i}\right)^{2}\right)}}
$$

Untuk menguji hubungan variabel $\mathrm{X}$ dan $\mathrm{Y}$, bandingkan nilai $\mathrm{r}$ hitung dengan nilai $\mathrm{r}$ tabel untuk taraf nyata $5 \%$. Apabila nilai $\mathrm{r}_{\text {hitung }}>\mathrm{r}_{\text {tabel }}$, berarti $\mathrm{H}_{0}$ ditolak dan $\mathrm{H}_{\mathrm{i}}$ diterima ${ }^{[5]}$. Untuk mengetahui koefisien determinasi dapat digunakan rumus:

$$
K D=r^{2} \times 100 \% \text {. }
$$

Dimana KD adalah koefisien determinasi, dan $r$ adalah koefisien korelasi.

Data kompetensi keterampilan diperoleh selama empat kali praktikum melalui rubrik penskoran masih dalam bentuk skor, maka harus dikonversi menjadi nilai dalam rentang 0-100. Teknik analisis data yang digunakan sama dengan teknik analisis data pada kompetensi pengetahuan.

\section{HASIL PENELITIAN DAN PEMBAHASAN}

\section{A. Hasil Penelitian}

Berdasarkan penelitian yang telah dilakukan pada kelas sampel, diperoleh data berupa data pencapaian kompetensi sikap, pengetahuan dan keterampilan peserta didik kelas X MIPA 1 SMAN 2 Padang Panjang.

Data kompetensi sikap diperoleh selama kegiatan pembelajaran menggunakan lembar penilaian observasi. Penilaian sikap dibatasi pada aspek jujur, percaya diri, kerja sama serta rasa ingin tahu. Data pencapaian kompetensi sikap peserta didik selama enam kali pertemuan dapat dilihat pada Tabel 1.

Tabel 1. Data Hasil Pencapaian Kompetensi Sikap Peserta Didik Kelas X MIPA 1

\begin{tabular}{|c|c|c|c|c|c|c|c|}
\hline \multirow{2}{*}{ Aspek } & \multicolumn{5}{|c|}{ Pertemuan Ke } & \multirow{2}{*}{$\begin{array}{c}\text { Rata } \\
\text {-rata }\end{array}$} \\
\cline { 2 - 6 } & $\mathbf{1}$ & $\mathbf{2}$ & $\mathbf{3}$ & $\mathbf{4}$ & $\mathbf{5}$ & $\mathbf{6}$ & \\
\hline Jujur & 77,2 & 77,2 & 79,4 & 82,4 & 81,6 & 87,5 & 80,88 \\
\hline Percaya Diri & 74,3 & 77,2 & 80,9 & 83,1 & 79,4 & 83,8 & 79,78 \\
\hline Kerja Sama & 77,2 & 78,7 & 78,7 & 84,6 & 86 & 85,3 & 81,75 \\
\hline $\begin{array}{c}\text { Rasa Ingin } \\
\text { Tahu }\end{array}$ & 77,9 & 80,1 & 80,9 & 86 & 82,4 & 83,1 & 81,73 \\
\hline $\begin{array}{c}\text { Nilai Akhir } \\
\text { Sikap }\end{array}$ & $\mathbf{7 6 , 6 5}$ & $\mathbf{7 8 , 3}$ & $\mathbf{7 9 , 9 7}$ & $\mathbf{8 4 , 0 2}$ & $\mathbf{8 2 , 3}$ & $\mathbf{8 4 , 9 2}$ & $\mathbf{8 1 , 0 2}$ \\
\hline
\end{tabular}

Data kompetensi pengetahuan diperoleh melalui tes akhir berupa posttest berbentuk soal objektif sebanyak 36 soal. Nilai tersebut dihubungkan dengan nilai yang diperoleh peserta didik dalam proses pembelajaran menggunakan modul berorientasi model pembelajaran inkuiri terbimbing untuk melihat seberapa besar pengaruh penerapannya terhadap nilai posttest peserta didik. Data tersebut dapat dilihat pada Tabel 2.

Tabel 2. Nilai Rata-rata Kompetensi Pengetahuan Peserta Didik

\begin{tabular}{|c|c|c|c|c|c|c|c|}
\hline & \multicolumn{6}{|c|}{$\begin{array}{c}\text { Nilai Proses Pembelajaran Menggunakan Modul } \\
\text { Berorientasi Model Inkuiri Terbimbing }\end{array}$} & $\begin{array}{c}\text { Nilai } \\
\text { Posttest }\end{array}$ \\
\hline & P1 & P2 & P3 & P4 & P5 & P6 & \\
\hline Rata-rata & 78,55 & 82,97 & 84,31 & 80,76 & 86,76 & 90,2 & 79,98 \\
\hline $\begin{array}{c}\text { Nilai } \\
\text { Maksimum }\end{array}$ & 91,67 & 95,83 & 95,83 & 91,67 & 100 & 100 & 94 \\
\hline $\begin{array}{c}\text { Nilai } \\
\text { Minimum }\end{array}$ & 66,67 & 75 & 75 & 75 & 75 & 79,17 & 69 \\
\hline Range & 25 & 20,83 & 20,83 & 16,67 & 25 & 20,83 & 25 \\
\hline Median & 79,17 & 81,25 & 83,33 & 79,17 & 87,5 & 89,58 & 79 \\
\hline Modus & 75 & 79,17 & 83,33 & 79,17 & 87,5 & 87,5 & 75 \\
\hline Varians & 38,02 & 45,63 & 30,58 & 18,95 & 57,31 & 35,65 & 44,79 \\
\hline $\begin{array}{c}\text { Standar } \\
\text { Deviasi }\end{array}$ & 6,166 & 6,755 & 5,529 & 4,354 & 7,571 & 5,971 & 6,693 \\
\hline $\begin{array}{c}\text { Standar } \\
\text { Rata-rata } \\
\text { Error }\end{array}$ & 1,057 & 1,158 & 0,948 & 0,747 & 1,298 & 1,024 & 1,148 \\
\hline
\end{tabular}

Data kompetensi keterampilan diperoleh setelah melakukan empat kali percobaan yaitu: 1) percobaan hukum kekekalan momentum; 2) tumbukan lenting sebagian; 3) hubungan massa dengan periode getar pada pegas; 4) hubungan panjang tali dengan periode ayun pada bandul sederhana. Data selama empat kali praktikum dapat dilihat pada Tabel 3.

Tabel 3. Data Kompetensi Keterampilan Peserta Didik

\begin{tabular}{|c|c|c|c|c|}
\hline & \multicolumn{4}{|c|}{ Percobaan } \\
\hline & I & II & III & IV \\
\hline Rata-Rata & 85,05 & 81,62 & 86,40 & 84,56 \\
\hline Maksimum & 91,67 & 87,5 & 91,67 & 87,5 \\
\hline Minimum & 79,17 & 79,17 & 79,17 & 81,67 \\
\hline Range & 12,5 & 8,33 & 12,5 & 5,83 \\
\hline Median & 87,5 & 79,17 & 87,5 & 85 \\
\hline Modus & 87,5 & 79,17 & 87,5 & 85 \\
\hline Varians & 20,12 & 9,60 & 17,16 & 2,91 \\
\hline Standar Deviasi & 4,49 & 3,09 & 4,14 & 1,71 \\
\hline $\begin{array}{c}\text { Standar Rata-Rata } \\
\text { Error }\end{array}$ & 0,77 & 0,53 & 0,71 & 0,29 \\
\hline
\end{tabular}

Analisis data kompetensi sikap peserta didik dideskripsikan dalam bentuk grafik untuk melihat pencapaian kompetensi sikap peserta didik pada setiap pertemuannya, apakah mengalami perubahan atau tidak. Pertemuan tatap muka (pertemuan ke) dalam sumbu $\mathrm{x}$ dan nilai rata-rata sikap peserta didik pada sumbu y. Grafik dibuat untuk setiap aspek sikap yang diamati, yaitu sikap jujur, percaya diri, kerja sama dan rasa ingintahu.

Sikap jujur peserta didik dibatasi pada indikator tidak menyontek pada saat mengerjakan tugas dan ulangan, membuat tugas dan laporan berdasarkan data yang diperoleh, dan menyampaikan pendapat sesuai dengan sumber yang benar. Rata-rata sikap jujur peserta didik dapat dilihat pada Gambar 1. 


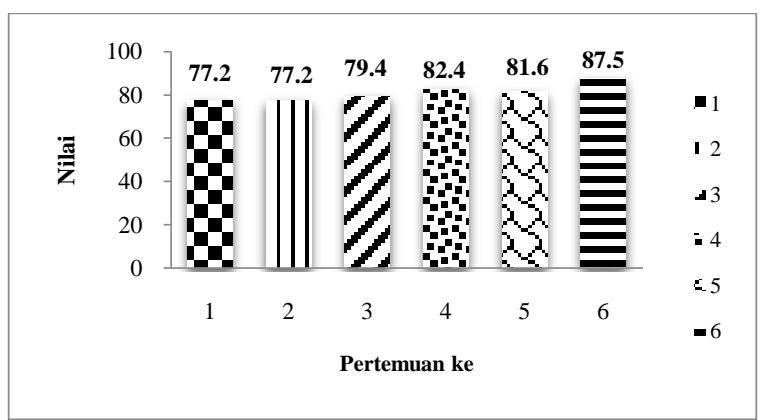

Gambar 1. Grafik Kompetensi Sikap Jujur Peserta Didik

Berdasarkan Gambar 1, nilai rata-rata sikap jujur peserta didik paling tinggi diperoleh pada pertemuan ke enam yaitu 87,5. Nilai rata-rata terendah terjadi pada pertemuan satu dan dua dengan nilai yang sama yaitu 77,2.

Sikap percaya diri peserta didik dibatasi pada indikator berani tampil didepan kelas, berani berpendapat, dan berani bertindak. Rata-rata sikap percaya diri peserta didik dapat dilihat pada Gambar 2.

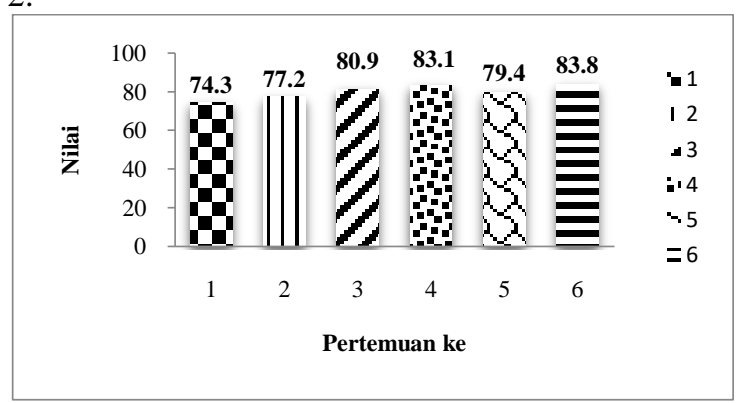

Gambar 2. Grafik Kompetensi Sikap Percaya Diri Peserta Didik

Berdasarkan Gambar 2, nilai sikap percaya diri peserta didik tertinggi pada pertemuan enam dengan nilai rata-rata 83,8 . Nilai sikap percaya diri paling rendah terjadi pada pertemuan pertama dengan nilai rata-rata 74,3 .

Sikap kerja sama dibatasi pada indikator aktif dalam diskusi kelompok dan bekerja sesuai kesepakatan kelompok. Rata-rata sikap bekerja sama peserta didik dapat dilihat pada Gambar 3.

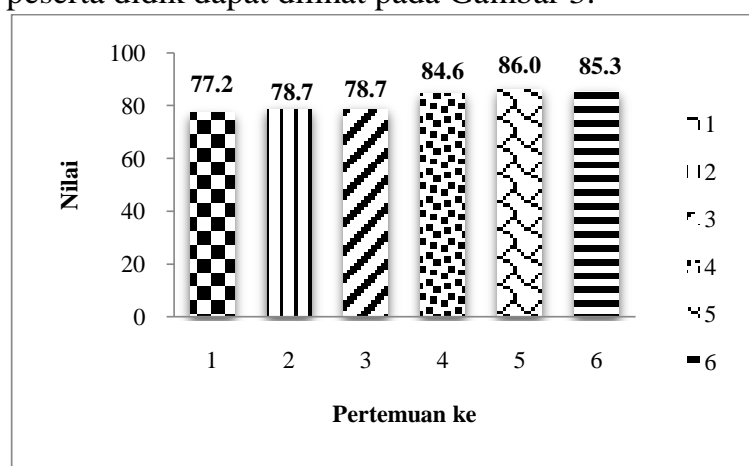

Gambar 3. Grafik Kompetensi Sikap Kerja Sama Peserta Didik
Berdasarkan Gambar 3, sikap bekerja sama peserta didik memperoleh nilai rata-rata tertinggi pada pertemuan ke lima dengan nilai 86. Nilai rata-rata peserta didik terendah pada pertemuan pertama dengan rata-rata 77,2 .

Sikap rasa ingintahu peserta didik dibatasi pada indikator antusias dalam kegiatan pembelajaran dan kegiatan diskusi, antusias dalam menemukan jawaban, serta mendengarkan penjelasan guru atau teman. Rata-rata nilai sikap rasa ingintahu peserta didik dapat dilihat pada Gambar 4.

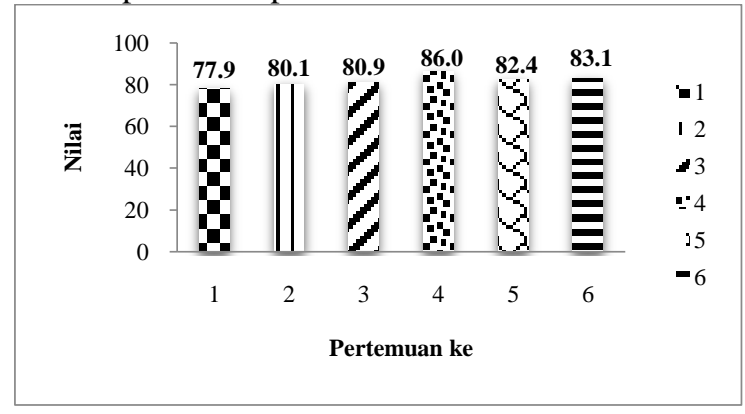

Gambar 4. Grafik Kompetensi Sikap Rasa Ingin tahu Peserta Didik

Berdasarkan Gambar 4, diketahui bahwa rata-rata nilai kompetensi sikap rasa ingin tahu peserta didik memperoleh nilai tertinggi pada pertemuan empat dengan nilai 86 dan terendah pada pertemuan pertama dengan nilai 77,9 .

Dari hasil analisis yang telah dilakukan, dapat disimpulkan bahwa sikap peserta didik cenderung mengalami perubahan pada setiap pertemuannya. Namun, secara keseluruhan pencapaian kompetensi sikap peserta didik sudah mencapai hasil yang baik.

Uji regresi pada kompetensi pengetahuan dinyatakan dalam persamaan regresi linier sederhana, yaitu $\mathrm{Y}=13,04+0,798 \mathrm{X}$. Persamaan regresi diperoleh dengan menghitung nilai $a$ dan $b$ terlebih dahulu menggunakan analisis uji regresi. Untuk menentukan keberartian dan uji linieritas, dapat ditentukan dengan menggunakan analisis anava seperti yang dapat dilihat pada Tabel 4 .

Tabel 4. Analisis Data Kompetensi Pengetahuan Menggunakan Anava

\begin{tabular}{|c|c|c|c|c|}
\hline $\begin{array}{l}\text { Sumber } \\
\text { Variansi }\end{array}$ & Dk & JK & KT & $\mathbf{F}$ \\
\hline Total & 34 & 219436 & 219436 & \\
\hline $\begin{array}{c}\text { Koefisien } \\
\text { (a) }\end{array}$ & 1 & 217920,12 & 217920,12 & \multirow{2}{*}{$\begin{array}{c}\mathrm{Fh}=8,65 \\
\mathrm{Ft}=4,12 \\
\mathrm{Fh}>\mathrm{Ft}\end{array}$} \\
\hline $\begin{array}{c}\text { Regresi } \\
\text { (b/a) }\end{array}$ & 1 & 322,48 & 322,48 & \\
\hline Sisa & 32 & 1193,39 & 37,29 & \\
\hline $\begin{array}{l}\text { Tuna } \\
\text { Cocok }\end{array}$ & 9 & 325,46 & 36,16 & \multirow{2}{*}{$\begin{array}{c}\mathrm{Fh}=1,61 \\
\mathrm{Ft}=2,23 \\
\mathrm{Fh}<\mathrm{Ft}\end{array}$} \\
\hline Galat & 23 & 867,933 & 22,45 & \\
\hline
\end{tabular}

Berdasarkan Tabel 4, setelah dilakukan analisis untuk menentukan uji keberartian adalah dengan membandingkan nilai $F_{\text {hitung }}$ dengan $F_{\text {tabel }}$. Syarat uji keberartian adalah koefisien regresi akan berarti 
jika nilai $F_{\text {hitung }}>F_{\text {tabel }}$. Nilai $F_{\text {hitung yang }}$ diperoleh dari hasil analisis adalah 8,65 dan nilai $F_{\text {tabel }}$ adalah 4,12. Dengan demikian diperoleh nilai $F_{\text {hitung }}>F_{\text {tabel }}$, dan berarti koefisien arah regresi tersebut berarti. Sedangkan untuk uji linieritas, nilai $F_{\text {hitung }}$ yang diperoleh adalah 1,61 dan nilai $F_{\text {tabel }}$ adalah 2,23. Syarat dalam uji linieritas adalah $F_{\text {hitung }}<F_{\text {tabel }}$. berdasarkan nilai yang diperoleh terlihat bahwa nilai $F_{\text {hitung }}<F_{\text {tabel }}$, artinya regresinya adalah linier. Setelah dilakukan uji keberartian dan uji linieritas, selanjutnya dilakukan uji hubungan dua variabel. Ketentuan dari uji ini adalah dengan membandingkan nilai $r_{\text {hitung }}$ dengan $r_{\text {tabel }}$. Jika nilai $r_{\text {hitung }}>r_{\text {tabel }}$, maka terdapat hubungan antara variabel terikat dengan variabel bebas. Berdasarkan analisis yang telah dilakukan, nlai $r_{\text {hitung }}$ sama dengan 0,461 dan $r_{\text {tabel }}$ sama dengan 0,339. Terlihat bahwa nilai $r_{\text {hitung }}>r_{\text {tabel }}$ dan dengan demikian, terdapat hubungan antara penggunaan modul berorientasi model pembelajaran inkuiri terbimbing dengan kompetensi pengetahuan peserta didik.

Hubungan antara penggunaan modul berorientasi model pembelajaran inkuiri terbimbing dengan kompetensi pengetahuan peserta didik dapat dilihat pada gambar 5 .

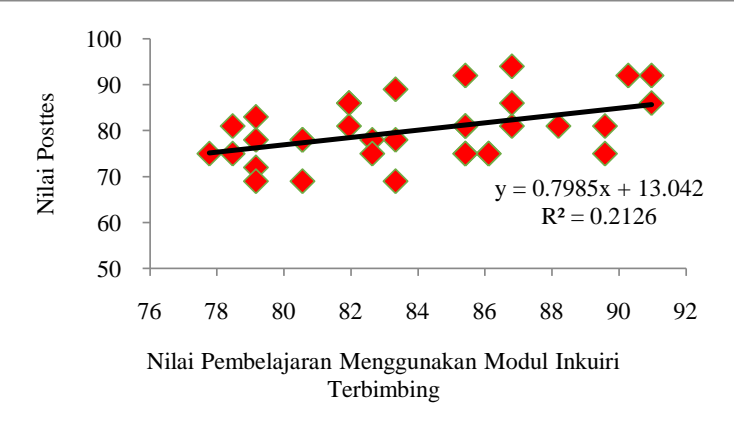

Gambar 5. Grafik Hubungan Nilai Modul dengan Kompetensi Pengetahuan Peserta Didik.

Dari Gambar 5 di atas terlihat bahwa data kompetensi pengetahuan peserta didik terdistribusi disekitar garis lurus (linear).

Untuk mengetahui besar pengaruh penggunaan modul berorientasi model pembelajaran inkuiri terbimbing terhadap kompetensi pengetahuan peserta didik, maka perlu dihitung koefisien determinasi. Setelah dilakukan perhitungan, nilai koefisien determinasi diperoleh sebesar 21,26\%. Artinya kompetensi pengetahuan peserta didik 21,26\% dipengaruhi oleh penggunaan modul berorientasi model pembelajaran inkuiri terbimbing dan 78,74\% dipengaruhi oleh faktor lainnya.

Pada kompetensi keterampilan, skor yang diperoleh pada rubrik penilaian unjuk kerja dikonversi terlebih dahulu ke dalam nilai dalam renatng 0-100, selanjutnya dilakukan analisis. Uji regresi pada kompetensi keterampilan dinyatakan dalam persamaan regresi linier sederhana, yaitu $\mathrm{Y}=68,76+0,18 \mathrm{X}$. Persamaan regresi diperoleh dengan menghitung nilai $a$ dan $b$ terlebih dahulu menggunakan analisis uji regresi. Untuk menentukan keberartian dan uji linieritas, dapat ditentukan dengan menggunakan analisis anava seperti yang dapat dilihat pada Tabel 5 .

Tabel 5. Analisis Data Kompetensi Keterampilan Menggunakan Anava

\begin{tabular}{|c|c|c|c|c|}
\hline $\begin{array}{l}\text { Sumber } \\
\text { Variansi }\end{array}$ & Dk & JK & KT & $\mathbf{F}$ \\
\hline Total & 34 & 22,62 & 22,62 & \\
\hline Koefisien (a) & 1 & 244694,68 & 244694,68 & \multirow{2}{*}{$\begin{array}{c}\mathrm{Fh}=8,13 \\
\mathrm{Ft}=4,12 \\
\mathrm{Fh}>\mathrm{Ft}\end{array}$} \\
\hline Regresi (b/a) & 1 & 15,92 & 15,92 & \\
\hline Sisa & 32 & 62,62 & 1,96 & \\
\hline Tuna Cocok & 11 & 22,62 & 2,056 & \multirow{2}{*}{$\begin{array}{c}\mathrm{Fh}=1,08 \\
\mathrm{Ft}=2,3 \\
\mathrm{Fh}<\mathrm{Ft}\end{array}$} \\
\hline Galat & 21 & 40,002 & 1,90 & \\
\hline
\end{tabular}

Berdasarkan Tabel 5, setelah dilakukan analisis untuk menentukan uji keberartian adalah dengan membandingkan nilai $F_{\text {hitung }}$ dengan $F_{\text {tabel }}$. Syarat uji keberartian adalah koefisien regresi akan berarti jika nilai $F_{\text {hitung }}>F_{\text {tabel }}$. Nilai $F_{\text {hitung yang }}$ diperoleh dari hasil analisis adalah 8,13 dan nilai $F_{\text {tabel }}$ adalah 4,12. Dengan demikian diperoleh nilai $F_{\text {hitung }}>F_{\text {tabel }}$, dan berarti koefisien arah regresi tersebut berarti. Sedangkan untuk uji linieritas, nilai $F_{\text {hiveri }}$ yang diperoleh adalah 1,08 dan nilai $F_{\text {tabel }}$ adalah 2,3. Syarat dalam uji linieritas adalah $F_{\text {hitung }}<F_{\text {tabel }}$. berdasarkan nilai yang diperoleh terlihat bahwa nilai $F_{\text {hitung }}<F_{\text {tabel }}$, artinya regresinya adalah linier. Setelah dilakukan uji keberartian dan uji linieritas, selanjutnya dilakukan uji hubungan dua variabel. Ketentuan dari uji ini adalah dengan membandingkan nilai $r_{\text {hitung }}$ dengan $r_{\text {tabel }}$. Jika nilai $r_{\text {hitung }}>r_{\text {tabel }}$, maka terdapat hubungan antara variabel terikat dengan variabel bebas. Berdasarkan analisis yang telah dilakukan, nlai $r_{\text {hitung }}$ sama dengan 0,45 dan $r_{\text {tabel }}$ sama dengan 0,34 . Terlihat bahwa nilai $r_{\text {hitung }}>r_{\text {tabel }}$ dan dengan demikian, terdapat hubungan antara penggunaan modul berorientasi model pembelajaran inkuiri terbimbing dengan kompetensi keterampilan peserta didik.

Hubungan antara penggunaan modul berorientasi model pembelajaran inkuiri terbimbing dengan kompetensi keterampilan peserta didik dapat dilihat pada Gambar 6. 


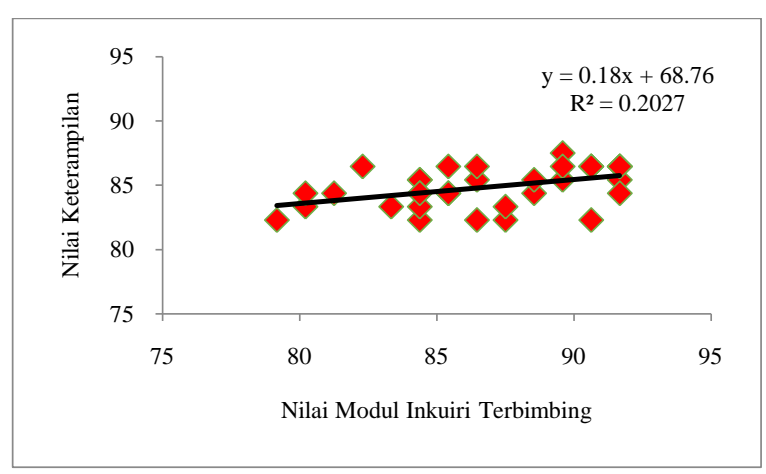

Gambar 6. Grafik Hubungan Nilai Modul dengan Kompetensi Keterampilan Peserta Didik.

Dari Gambar 6 terlihat bahwa data kompetensi keterampilan peserta didik terdistribusi disekitar garis lurus (linier).

Untuk mengetahui besar pengaruh penggunaan modul berorientasi model pembelajaran inkuiri terbimbing terhadap kompetensi keterampilan peserta didik, maka perlu dihitung koefisien determinasi. Setelah dilakukan perhitungan, nilai koefisien determinasi diperoleh sebesar 20,27\%. Artinya kompetensi keterampilan peserta didik 20,27\% dipengaruhi oleh penggunaan modul berorientasi model pembelajaran inkuiri terbimbing dan $79,73 \%$ dipengaruhi oleh faktor lainnya.

Data pencapaian kompetensi keterampilan peserta didik juga dideskripsikan dalam bentuk grafik untuk melihat perkembangan keterampilan peserta didik berdasarkan kegiatan praktikum yang dilakukan. Kegiatan praktikum (praktikum ke) dinyatakan dalam sumbu $\mathrm{x}$ dan nilai rata-rata praktikum dinyatakan dalam sumbu y. Berdasarkan data yang diperoleh, kompetensi keterampilan peserta didik setelah melakukan empat kali praktikum dapat dilihat pada Gambar 7.

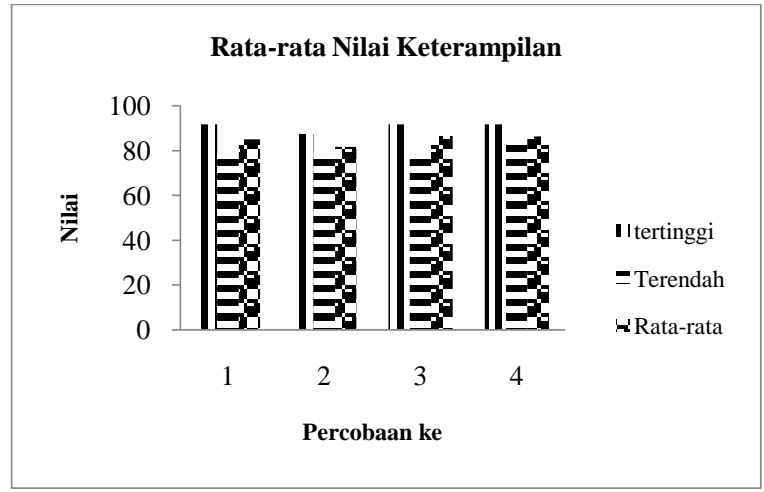

Gambar 7. Grafik Nilai Rata-rata Kompetensi Keterampilan Peserta Didik

Berdasarkan Gambar 7 pada percobaan pertama nilai tertinggi yang diperoleh adalah 91,67 , nilai terendah adalah 75 , nilai rata-rata pada percobaan pertama adalah 83,46 . Pada percobaan kedua, nilai tertinggi adalah 87,5 , nilai terendah 79,17 , nilai rata-rata adalah 81,62. Pada percobaan ketiga, nilai maksimum adalah 91,67, nilai terendah adalah 79,17, nilai rata-rata adalah 86,4 . Pada percobaan keempat, nilai tertinggi adalah 87,5 , nilai terendah adalah 81,67 , dan nilai rata-rata adalah 84,56. Dari keempat percobaan yang telah dilakukan dapat disimpulkan bahwa nilai tertinggi kompetensi keterampilan peserta didik adalah 91,67 yaitu pada percobaan pertama dan ketiga, sedangkan nilai terendah yang diperoleh adalah adalah 75 yaitu pada percobaan kedua. Rata-rata tertinggi dari kompetensi keterampilan peserta didik adalah 86,4 yang diperoleh pada percobaan ketiga.

\section{B. Pembahasan}

Penilaian kompetensi sikap dilakukan pada setiap kali pertemuan yang dilakukan menggunakan lembar penilaian observasi. Penilaian kompetensi sikap dibatasi pada sikap jujur, percaya diri, bekerja sama, dan rasa ingin tahu. Berdasarkan analisis data yang telah dilakukan, pada kompetensi sikap peserta didik belum menunjukkan kekonsistetan, cenderung mengalami kenaikan atau penurunan pada setiap minggunya. Namun, secara keseluruhan kompetensi sikap peserta didik sudah menunjukkan sikap yang baik.

Pada kompetensi pengetahuan, nilai posttest yang akan diperoleh peserta didik akan sesuai dengan nilai proses pembelajaran menggunakan modul berorientasi model pembelajaran inkuiri terbimbing. Peserta didik yang mengikuti setiap langkah yang ada di dalam modul akan memperoleh nilai posttest yang baik pula. Hal ini diketahui setelah dilakukan uji keberartian dan uji hubungan dua variabel, bahwa terdapat pengaruh penggunaan modul berorientasi model pembelajaran inkuiri terbimbing terhadap kompetensi pengetahua peserta didik dan terdapat hubungan antara keduanya. Namun, kenyataannya masih ada beberapa peserta didik yang kurang mengikuti pembelajaran menggunakan modul berorientasi model pembelajaran inkuiri terbimbing dengan sungguh-sungguh tetap mendapat nilai posttest yang baik, begitupun sebaliknya. Hal ini diketahui berdasarkan uji hubungan dua variabel yang didapatkan, bahwa $21,26 \%$ kompetensi pengetahuan peserta didik dipengaruhi oleh perlakukan yang peneliti terapkan dan $78,74 \%$ lagi dipengaruhi oleh faktor lain. Hal ini menandakan bahwa penggunaan modul berorientasi model pembelajaran inkuiri terbimbing bukanlah satusatunya faktor yang mempengaruhi pencapaian kompetensi pengetahuan peserta didik, masih ada faktor lain yang ikut berpengaruh tanpa dapat peneliti kendalikan.

Penerapan modul berorientasi model inkuiri terbimbing dalam pembelajaran dapat meningkatkan rasa percaya diri peserta didik melalui kegiatan mengajukan hipotesis. Dalam kegiatan ini peserta didik diberikan kesempatan untuk berpendapat terhadap hasil pengamatannya. Hal ini sesuai dengan pendapat Sanjaya (2008:197) bahwa seluruh aktivitas peserta didik diarahkan untuk mencari dan 
menemukan jawaban sendiri dari sesuatu yang dipertanyakan, sehingga dapat menumbuhkan rasa percaya diri.

Penggunaan modul berorientasi inkuiri terbimbing ini juga dapat meningkatkan kemampuan menemukan dan membangun pengetahuan peserta didik secara mandiri. Di dalam modul ini tersedia kolom 'ramen (rajin menyelidiki)', pada kolom ini terdapat bagian kosong yang harus peserta didik isi hingga diperoleh suatu perumusan. Dengan demikian peserta didik dibiasakan belajar dalam mengkonstruk pengetahuannya sendiri, tidak selalu menerima begitu saja. Karena pengetahuan yang diperoleh peserta didik sendiri akan lebih bermakna jika dibandingkan dengan hanya mendengar atau menerima dari orang lain. Hal ini sesuai dengan pendapat Hosnan (2014:340) bahwa belajar dengan menyelidiki dan menemukan sendiri sebuah pengetahuan yang baru akan lebih bermakna dan lebih melekat dalam daya ingat dibandingkan dengan belajar yang hanya menerima dan menyerap apa yang disampaikan oleh orang lain, terlebih lagi jika hanya mengahafal pengetahuan yang pada akhirnya dapat mengganggu keseimbangan potensi diri peserta didik.

Pada kompetensi keterampilan, setelah dilakukan analisis uji keberartian dan uji hubungan dua variabel diperoleh hasil bahwa kompetensi keterampilan peserta didik 20,27\% dipengaruhi oleh penggunaan modul berorientasi model pembelajaran inkuiri terbimbing dan terdapat hubungan antara keduanya. Selama kegiatan percobaan, peserta didik diberi kesempatan untuk mendapatkan suatu pembuktian antara teori yang dipelajarinya dengan data yang diperolehnya. Kegiatan praktikum ini juga dapat melatih peserta didik dalam bekerja sama dan bertanggung jawab. Hal ini peneliti ketahui ketika melakukan percobaan tumbukan lenting sebagian yang menggunakan bola tenis, masih ada anggota kelompok yang tidak membawanya. Ketika ditanya, mereka masih saling meyalahkan satu sama lain dan beralasan bola dibawa oleh anggota kelompok yang lainnya. Selain itu melalui kegiatan praktikum ini juga dapat melatih pentingnya interaksi antar anggota kelompok dan bertanggung jawab atas tugas yang telah disepakati bersama. Melalui kegiatan kemampuan peserta didik untuk menemukan suatu pengetahuan dapat dikembangkan. Karena berdasarkan pengamatan, peserta didik cenderung lebih aktif dalam pembelajaran yang disertai kegiatan praktikum.

\section{KESIMPULAN}

Setelah dilakukan penelitian dan dilanjutkan dengan menganalisis data hasil penelitian dapat disimpulkan bahwa penggunaan modul berorientasi model pembelajaran inkuiri terbimbing memiliki pengaruh yang berarti terhadap pencapaian kompetensi fisika peserta didik kelas X SMAN 2 Padang Panjang. Pada kompetensi sikap menunjukkan hasil yang baik meskipun mengalami perubahan nilai pada setiap pertemuannya. Penggunaan modul berorientasi model pembelajaran inkuiri terbimbing mempengaruhi pencapaian kompetensi pengetahuan sebesar 21,26\%. Penggunaan modul mempengaruhi pencapaian kompetensi keterampilan peserta didik sebesar $20,27 \%$

\section{DAFTAR PUSTAKA}

[1] Daryanto. 2014. Pendekatan Pembelajaran Saintifik Kuirkulum 2013. Yogyakarta: Gava Media.

[2] Depdiknas. 2008. Panduan Pengembangan Bahan Ajar. Jakarta: Direktorat Jenderal Manajemen Pendidikan Dasar dan Menengah.

[3] Hosnan. 2014. Pendekatan Saintifik dan Kontekstual Dalam Pembelajaran Abad 21: Kunci Sukses Implementasi Kurikulum 2013. Bogor: Ghalia Indonesia.

[4] Abidin, Yunus. 2014. Desain Sistem Pembleajaran dalam Konteks Kurikulum 2013. Bandung: PT. Refika Aditama.

[5] W. Gulo. 2008. Strategi Belajar Mengajar. Jakarta: Grasindo.

[6] Sugiyono. 2012. Metode Penelitian Kuantitatif, Kualitatif, dan $R \& D$. Bandung: Alfabeta.

[7] Arikunto, Suharsimi. 2012. Dasar-Dasar Evaluasi Pendidikan. Jakarta: Bumi Aksara.

[8] Sanjaya, Wina. 2008. Strategi Pembelajaran. Jakarta: Kencana Prenada Media Group.

[9] Pratama, Kurnia Heru, Hidayati \& Ramli. 2017. Pengaruh Penerapan Lembar Kerja Peserta Didik Berbasis Pendekatan Saintifik dalam Model Pembelajaran Inquiry Terhadap Kompetensi Fisika Peserta Didik Kelas X SMAN 13 Padang. Pillar of Physics Education, Vol. 9. April 2017, 81-88.

[10] Yenni, Rozi Prima, Masril \& Hidayati. 2016. Pengaruh Penerapan Bahan Ajar Berbasis Pendekatan Saintifik Melalui ICT dalam Model Pembelajaran Inquiry Terhadap Kompetensi Fisika Siswa Kelas $X$ SMAN 1 Padang. Pillar of Physics Education, Vol. 7. April 2016, 01-08. 